M. 67 (colour indices measured by Shapley) appears to be almost entirely made up of $g$ stars, and contains neither $b$ nor $m$ classes, reminding us forcibly of the frequent association of the corresponding spectral types among the isolated stars.

Very significantly, in neither case does colour or magnitude vary with condensation. On the other hand, colour and magnitude are found to be connected, showing a marked relationship in the case of N.G.C. 1647 , less pronounced in M. 67.

\section{THE COLUMBUS MEETING OF THE AMERICAN ASSOCIATION FOR THE ADVANCEMENT OF SCIENCE.}

THE sixty-eighth annual meeting of the American Association for the Advancement of Science was held at Columbus, Ohio, from December 27, I915, to January $\mathrm{r}$, under the presidency of Dr. W. W. Campbell, director of the Lick Observatory of the University of California. In spite of the fact that the second Pan-American Scientific Congress was held at the same time in Washington, D.C., there was an attendance of something more than eight hundred, and the meeting was unusually successful.

The address of the retiring president,. Dr. C. W. Eliot, on the subject, "The Fruits, Prospects, and Lessons of Recent Biological Science," has already been printed in NaTuRE (January 27 , p. 605). Addresses of presidents of sections were given as follows :-(A) H. S. White, "Poncelet Polygons"; (B) A. Zeleny, "The Dependence of Progress in Science upon the Development of Instruments"; (F) F. R. Lillie, "The History of the Fertilisation Problem"; (G), G. P. Clinton, "Botany in Relation to American Agriculture"; (H) C. Wissler, "Psychological and Historical Interpretations of Culture"; (I) E. E. Rittenhouse, "Upbuilding American Vitality: the Need for a Scientific Investigation"; (K) R. M. Pearce, "The Work and Opportunities of a University Department for Research in Medicine"; (L) P. H. Hanus, "City School Superintendents' Reports"; (M) L. H. Bailey, "The Forthcoming Situation in Agricultural Work."

One of the most interesting functions of the meetings was a public lecture complimentary to the citizens of Columbus by Dr. D. W. Johnson, professor of physiography at Columbia University, on "Surface Features of Europe as a Factor in the War." Dr. Johnson indicated the strategic reasons for the movements in the great war which have been dependent upon the character of the country involved, and threw a new light on the subject to those who have been puzzled especially by the operations in the eastern war zone. Other public lectures were delivered by Dr. R. F. Bacon, of the Mellon Institute of Pittsburgh, on "The Industrial Fellowships of the Mellon Institute: Five Years' Progress in a System of Industrial Service"; Dr. F. K. Cameron, of the Bureau of Soils, Washington, "The Fertiliser Resources of the United States."

An important symposium on the topic, "The Basis of Individuality in Organisms," was held by Section F and the American Society of Zoologists.

Section K conducted a symposium on the topic, "Foods and Feeding," in the course of which Prof. H. B. Armsby spoke of the "Energy Content of the Diet"; Prof. Ruth Wheeler on the "Effect of the Proteid Constituents of the Diet on Growth"; Prof. E. B. Forbes, "The Mineral Nutrients in Practical Human Dietetics"; Prof. Carl Voegtlin, "Vitamines"; Dr. C. F. Langworthy, "Food Selection for Rational and Economical Living."

The new section of Agriculture, Section M, conducted a symposium on the topic, "The Relation of
Science to Meat Production," in which President W. O. Thompson (Ohio State University), President H. J. Waters (Kansas State Agricultural College), Prof. L. D. Hall (Office of Markets, U.S. Department of Agriculture), Prof. H. W. Mumford (University of Illinois), and Dr. A. R. Ward (Bureau of Animal Industry, U.S. Department of Agriculture) took part.

The following affiliated societies met with the American Association for the Advancement of Science:-American Association of Economic Entomologists, American Mathematical Society, American Microscopical Society; American Nature-Study Society, American Physical Society, American Phytopathological Society, American Society of Naturalists, Association of Official Seed Analysts of North America, Botanical Society of America; Entomological Society of America, Society for Horticultural Science, Southern Society for Philosophy and Psychology, Students and Collectors of Ohio Archæology; Wilson Ornithological Club.

New York was chosen as the meeting place for Convocation: Week of 1916-17.

Dr. C. R. Van Hise, president of the University of Wisconsin, a distinguished geologist, was elected president of the association for the next year. The vicepresidents - that is, presidents of sections-elected were as follows :-Mathematics, L. P. Eisenhart, Princeton University; Physics, H. A. Bumstead, Yale University; Engineering, E. L. Corthell, Brown University, Providence, R.I.; Geology and Geography, R. D. Salisbury, University of Chicago; Zoology, G. H. Parker, Harvard University; Botany, T. J. Burrill, University of Illinois; Anthropolgy and Psychology, F. W. Hodge, chief of the Bureau of Ethnology, Washington, D.C.; Social and Economic Science, Louis I. Dublin, New York; Education, L. P. Ayres, of the Russell Sage Foundation, New York; Agriculture, W. H. Jordan, director of the New York State Experiment Station, Geneva, N.Y.

The general committee reaffirmed the recently adopted policy of the association in regard to the planning of future meetings, establishing a five years' schedule, largely for the benefit of the affiliated societies in making their plans for the future.

Members of the association who attended the last Columbus meeting in 1899 were greatly impressed by the growth of the Ohio State University during the intervening years, a growth, however, which is characteristic of a number of the great State universities in the United States. At the time of the 1809 meeting there were only one thousand students at this University, and at the time of the present meeting there are more than five thousand. Very many new buildings have been erected in the interim, and the equipment of all is modern and most excellent.

\section{PARIS ACADEMY OF SCIENCES: PROPOSED PRIZES AND GRANTS.}

\section{Prizes Proposed FOR I9I7.}

Mathematics.--The Francœur prize (Iooo francs) will be awarded to the author of discoveries or works useful to the progress of pure or applied mathematics; the Bordin prize (300o francs), for an improvement in some important point of the arithmetical theory of non-quadratic forms; the Poncelet prize (2000 francs), to the French or foreign author of the most important work in applied mathematics published in the course of the preceding ten years; the Vaillant prize (4000 francs), the question set for 1917 is to determine and study all surfaces which can in two different ways be formed by the displacement of an invariable curve.

Mechanics.-The Montyon prize (7oo francs), for inventing or improving instruments useful to the pro- 
gress of agriculture, mechanical arts, and the practical and speculative sciences; the Fourneyron prize (Iooo francs), for the theoretical and experimental study of the question of combustion or explosion turbines; the Pierson-Perrin prize (5000 francs), for a discovery in mechanics.

Astronomy.-The Pierre Guzman prize (ıо,000 francs), to anyone finding a means of communication with a planet other than Mars, that is to say, to make a signal and receive a reply; the Lalande prize ( 540 francs), for observation or memoir most useful to the progress of astronomy; the Valz prize ( 460 francs), for similar work; the G. de Pontécoulant prize ( 700 francs), for the encouragement of researches in celestial mechanics; the Damoiseau prize (2000 francs), question for 1917 , to calculate more exactly, taking the results of recent expeditions into account, the attraction of the moon on the wave formed at the surface of the earth by the tides. To examine the effect of this attraction on the angular velocity of the earth's rotation.

Geography.-The Tchihatchef prize (300o francs), for the recompense or assistance of explorers in Asia (excluding British India, Siberia, Asia Minor, and Syria). The explorations may have as an object any branch of mathematical, physical, or natural science, excluding such sciences as archæology, history, ethnography, and philology. The work must result from actual observations made on the spot. Gay prize (I500 francs), the question proposed is the geographical distribution of tropical and subtropical plants presenting practical interest.

Navigation.- The extraordinary prize of 6000 francs for any progress of a nature as to increase the efficacy of the French naval forces; the Plumey prize (4000 francs), for the author of improvements in steam engines or any other invention contributing to the progress of steam navigation.

Physics. - The Hébert prize (Iooo francs), for the best treatise or work for the popularisation and practical employment of electricity; the Hughes prize (2500 francs), for an original discovery in the physical sciences, especially electricity and magnetism and their applications; the Henri de Parville prize (I500 francs), for original work in physics; the Gaston Planté prize (3000 francs), for an important invention or work in the field of electricity.

Chemistry.--The Jecker prize (Io,000 francs), for works leading to progress in organic chemistry; the Cahours prize (3000 francs), for the encouragement of young chemists who have already published good work; the Montyon prize (unhealthy trades; a prize of 2500 francs and a mention of 1500 francs), for a means of rendering an art or calling less unhealthy; the Houzeau prize (700 francs), for rewarding a promising young chemist; the Berthelot prize (500 francs), for researches in chemical synthesis.

Mineralogy and Geology.-The Delesse prize (1400 francs), for work in geology or mineralogy ; the Joseph Labbé prize (rooo francs), for geological work or researches contributing to the mineral wealth of France, its colonies, or dependencies; the Victor Raulin prize ( 1500 francs), for work in geology or palæontology; the Fontannes prize (2000 francs), to the author of the best palæontological publication; the James Hall prize (700 francs), for the best thesis for the doctorate in geology during the last five years.

Botany.-The Desmazieres prize (I6oo francs), for the best work published during the preceding year on Cryptogams; the Montagne prize (I500 francs), for work bearing on the anatomy, physiology, development, or description of the lower Cryptogams; the de Coincy prize ( 900 francs), for work on Phanerogams; the Thore prize (200 francs), for the best work on the cellular Cryptogams of Europe; the Jean de Rufz de
Lavison prize (500 francs), for work in plant physiology.

Anatomy and Zoology.-The Savigny prize (I500 francs), for the assistance of young travelling zoologists, not in receipt of Government grants, and who occupy themselves with the invertebrates of Egypt and Syria; the Cuvier prize ( 1500 francs), for work in comparative anatomy and zoology.

Medicine and Surgery.--The Montyon prize (a prize of 2500 francs, mentions of 1500 francs), for works most useful in the art of healing; the Barbier prize (2000 francs), for a valuable discovery in surgical, medical, or pharmaceutical science, or in botany in relation to medicine; the Bréant prize (100,0oo francs), for a radical cure for Asiatic cholera; the Godard prize (1000 francs), for the best work on the anatomy, physiology, and pathology of the genito-urinary organs; the Baron Larrey prize ( $75^{\circ}$ francs), for the best work on the subjects of medicine, surgery, or military hygiene; the Bellion prize (I 400 francs), for works or discoveries "profitable to the health of man or to the amelioration of the human species"; the Mège prize (10,00o francs), for the continuation and completion of Dr. Mège's essay on the causes which have retarded or favoured the progress of medicine from antiquity down to the present time; the Argut prize ( 1200 francs), for a discovery of a cure for a disease which at present can only be treated surgically, thus enlarging the domain of medicine.

Physiology.-The Montyon prize (750 francs), for work in experimental physiology; the Philipeaux prize (900 francs), for the same; the Lallemand prize (I80o francs), to recompense or encourage works relating to the nervous system in the widest sense; the Pourat prize (Iooo francs), the subject proposed is the relations of the combined sugar of the blood with the albumenoid materials, the Fanny. Emden prize (3000 francs), for the best work dealing with hypnotism, suggestion, and generally with physiological actions which can be exercised on the animal organism at a distance.

Statistics.-The Montyon prize (prize of 1000 francs and two mentions of 500 francs).

History and Philosophy of the Sciences.-.The Binoux prize (2000 francs).

General Prizes.-The Arago medal; the Lavoisier medal, for eminent service in chemistry; the Berthelot medal, awarded each year to the prizewinners in the subject of chemistry; the Henri Becquerel foundation (3000 francs); the Gegner prize (3800 francs); the Lannelongue foundation (2000 francs), for the assistance of one or two persons in reduced circumstances who belong to the scientific world, either themselves or by marriage or by parentage; the Gustave Roux prize (1000 francs); the Trémont prize (I000 francs); the Wilde prize (one prize of 4000 francs, or two of 2000 francs), for a work or discovery in astronomy, physics, chemistry, mineralogy, geology, or experimental mechanics; the Lonchampt prize (4000 francs), for the best memoir on diseases of man, animals, or plants, from the special point of view of the introduc tion of mineral substances in excess as the cause of these diseases; the Saintour prize (3000 francs), for work in mathematical science; the Henri de Parville prize (2500 francs), for a book dealing either with original work or with the popularisation of science; the Vaillant prize (4000 francs), (see under mathematics); prize founded by the State (3000 francs); grand prize of the physical sciences, subject proposed for 1917 , the modifications presented by trypanosomes in the bodies of insects; the Petit d'Ormoy prize (two prizes of 10,000 francs), one for pure and applied mathematics, and one for the natural sciences; the Serres prize ( 7500 francs), for works on general embryology, applied so far as possible to physiology and No. 24I4, vol. 96] 
medicine; the Alhumbert prize (1000 francs), question proposed for 1917 , the study of the action of the magnetic field on crystalline liquids; the prize founded by Mme. la Marquise de Laplace, to the pupil holding the first place leaving the Ecole Polytechnique; the Fêlix Rivot prize ( 2500 francs), between the four pupils leaving the Ecole Polytechnique with first and second places in mines and ponts et chaussées.

\section{The Loutreuil Foundation.}

As this is the first distribution of this fund, a summary is given of the regulations formulated by the committee for dealing with applications.

The grants recommended fall into three classes:-

(I) To institutions specially mentioned in the will of the founder.

The Natural History Museum, rooo francs for the continuation of researches on orchids undertaken by Prof. J. Costantin, and 5700 francs for the purchase of accumulators, and 4300 francs for a radiographic installation needed in the laboratory of Prof. Jean Becquerel.

The College de France, 4000 francs to G. Gley, for the installation of an apparatus in his laboratory for the production of cold; 5000 francs to $L$. Cayeux, for completing the equipment of his geological laboratory for petrographical researches; 2400 francs to $M$. Müntz, director of the laboratory of vegetable chemistry of Meudon; 2000 francs to L. Nattan-Larrier for the purchase of a centrifuge and incubator for cultures of micro-organisms.

As the provincial observatories are all attached to the universities which have already received a special legacy from M. Loutreuil, the council will only consider claims for grants relating to researches of a personal order. Under this head 3000 francs is granted to M. Gonessiat, director of the Algiers Observatory, for the construction of an apparatus designed to measure the intensity of Hertzian waves and for a vertical seismograph.

Polytechnic School, zooo francs to E. Carvallo, for the continuation of his researches on a method of shooting at airships.

The veterinary schools of Lyons and Alfort, each 5000 francs, for the upkeep of their libraries; the veterinary school of Toulouse, 3000 francs for the same purpose, and 1000 francs to $M$. Montane, for the reorganisation of the anatomical collections of this school.

(2) To institutions admitted by the president of the academy to participate in grants from the Loutreuil Fund.

The Conservatoire des Arts et Metiers : 3000 francs to Marcel Deprez, for his experiments relating to the transmission of the heat of gases to metallic walls, constantly cooled, and for experiments on electrical phenomena arising from internal-combustion motors; 4500 francs to $\mathrm{A}$. Job, for the purchase of a calorimetric bomb, an electric transformer, and other apparatus necessary to his researches on the velocities of oxidising reactions; 6000 francs to Jules Amar, for improving his equipment for the study of the muscular forces of man at work by the graphic and chronophotographic methods.

(3) To other societies and to individuals.

The Société de documentation bibliographique, 2000 francs; 2000 francs to Henri Piéron, for the equipment of his laboratory at the Sorbonne for physiological psychology; 2400 francs to Louis Mengaud, professor at the Lycée of Toulouse, for exploratory work in the province of Santander; Io,000 francs to Charles Marie, for assistance in the publication of tables of physical constants; 3000 francs to Camille Flammarion, for his private observatory at Juvisy; 4000 francs to Emile No. 2414 , VOL. 96$]$
Miège, for experiments at Rennes; Iooo francs for the preparation of plates illustrating fossils collected by J. Couyat-Barthoux.

The total grants recommended amount to 82,300 francs, and this does not exhaust the sum available. During the war it has been impossible for all the investigators to carry on work already commenced or to undertake new researches, and other expenditure considered desirable by the council has been excluded by the terms of the legacy.

\section{BRITISH METEOROLOGY.I}

WING to the war every side of the work of the Meteorological Office has been affected, and many alterations in the staff have taken place, although it is highly satisfactory to note that in this period of emergency the office has risen in every way to the everincreasing demands made on it by the Admiralty. This high efficiency is the outcome of the progressive development, organisation, and co-ordination of the work in all the divisional sections of the office and of the observations attached to it, gradually and systematically carried out, under the direction of Sir Napier Shaw, in the years preceding the outbreak of hostilities. Although all branches have supplied their quota of indispensable information to the authorities, the services rendered by the forecast division are more conspicuous than in other directions, so that it occasions no surprise to read that this division "has not failed to meet promptly and efficiently whatever wishes the Admiralty has expressed for information as to the weather over any part of the British Isles and neighbouring seas, for the use of the Navy, the Air Department, or the officials at headquarters."

The C.G.S. system of units for the expression of meteorological measurements has continued to make headway, and is being gradually introduced into all the publications. In this connection it is noted that the substitution of the millimetre for the inch in the measurement of rainfall "has met with less appreciation" than the other radical changes in progress. The necessity of uniformity is well shown by the publication of data dealing with the meteorology of the globe for I9II on the basis of two stations for each $10^{\circ}$ square, which is at present passing through the press under the title of the "Réseau Mondial, Igri." In this publication pressure is given in millibars, temperature in degrees absolute, and rainfall in millimetres for all stations.

A request received early in 1914 through the Foreign Office and the Board of Agriculture and Fisheries regarding the application in this country of meteorology to agriculture, forms the subject of an exhaustive reply given in extenso in appendix 2. It is pointed out that the line hitherto taken by the Meteorological Office, "as guided by tradition and precedent," has been to supply information likely to be of value to agriculturists in the form of weather forecasts and statistical reports, leaving the application of the data to the problems on hand to any who are disposed to take advantage of the material provided. The office resources do not include a staff to elucidate the questions involved, and a similar position obtains at the Board of Agriculture and Fisheries. The data provided are but little used by agriculturists. "Many persons are willing to receive forecasts by telegraph, but are unwilling to pay for the telegrams," and as the British race is not in the habit of paying for anything until its value has been amply denonstrated, both the Government and the farmer are waiting for the prac-

1 Tenth Annual Report of the Meteorological ('ommittee to the Lurds Commissioners of His Majesty's Treasur' for the Year ended March $3 \mathrm{~T}$

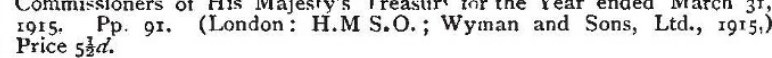

